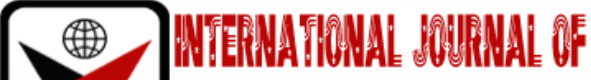 \\ X
}

ISSN 2278-0211 (Online)

\section{Effectiveness of Learner Centered Methods on Enhancing Teaching and Learning Process in Public Secondary Schools Moshi District, Tanzania}

\begin{tabular}{c} 
Tatu Waziri \\
Student, Department of Education, Mwenge Catholic University, Tanzania \\
Catherine Muteti \\
Lecturer, Department of Educational Management, Planing, Finance and Long Life Learning, \\
Mwenge Catholic University, Tanzania \\
Victorine Salema \\
Lecturer, Department of Education, Mwenge Catholic University, Tanzania \\
\hline
\end{tabular}

\begin{abstract}
The study was to investigate the effectiveness of learner centre methods on enhancing the teaching and learning processin public secondary schools in Moshi District Council, Tanzania. The problem of the study was answered by two (2) research questions. The researcher adopted a mixed-methods approach under which a convergent design was used.The study sampled 8 heads of schools, 8 academic teachers, 48 teachers and 160 form four students from 8 secondary schools and 1 district education officer, making a total number of 217 respondents. Information for this study was collected using questionnaires, interview guide and observation guide. Data were analyzed by the computer software that is a statistical package for social science (SPSS). The study found that learner centred teaching methods were applied at public secondary schools in the Moshi district. The study found that the majority of teachers applied learner centred teachingmethodson enhancing the teaching and learning process. Based on the findings, it was concluded that teachers used presentation, group discussion, questions and answers during the teaching and learning process. The study recommended that the government through the Ministry of Education Science and Technology (MOEST) should allocate enough funds to secondary schools for buying teaching and learning material that supported the application of learner centred teaching methods.
\end{abstract}

Keywords: Learner centered methods, Public secondary schools, Class size, Teachers' workload

\section{Introduction}

Learner-centered teaching methods are a teaching method that focuses on the needs of the learners so that they can get involved in the educational process (Simasiku, 2011). The learner- centered paradigm departs from the traditional teaching methods by focusing on learners more than teachers and the learning of the child more than the teaching by the teacher. In this case, learner centered teaching methods might allow for the active involvement and participation of learners in the learning process (Nyimbili, Namuyamba, and Chakanika, 2018). Teachers may structure their classes to facilitate this active learner role which may improve students' ability to understand various concepts. This means organizing learners in smaller or larger groups, or pairs, or working with them individually which make them responsible for learning while the teacher is responsible for facilitating the learning.

Historically, learner centered teaching methods in Tanzania began to be implemented in 2005 when the Government of the United Republic of Tanzania reviewed her curriculum from the traditional method of teaching to learner centered teaching (URT, 2010). Learner centered teaching encourages the use of participatory teaching methods. Learner centered teaching methods encourage interaction among teachers, students, the content and the environment in which learning occurs (Daniel, 2018). Learner centered methods can encourage interaction among students especially students who are reluctant to speak out in class because they feel that others in the class have the same thoughts, although they may have solved in different ways. This teaching method increases students' ability to manage difficult learning tasks.

According to Beinomugisha, Jagero and Rwashema (2012) learner centered teaching methods might be applied in the classroom by using several teaching techniques include; group-discussion, academic controversy (debating), role-play, problem-based learning, mind mapping, concept attainment, inductive learning. Learner centered teaching methods to create learning whereby students are not passive members in the teaching and learning process, is the teaching methods by which students are to the fullest engaged in teaching activities within their preferably learning styles.

The implementation of learner centered teaching methods in Tanzania education system has been an issue of concern. Many teachers and educationists largely depend on long-established habits (Nara, 2017). Learner centered 
teaching methods have been deployed since the education policy of self-reliance, but it was poorly utilized by many teachers as students have not been encouraged to work in groups largely discussing questions without proper direction (Tilya\&Mafumiko, 2010). For learner centered teaching methods to be implemented well in public secondary schools, it might depend on the teacher's perception about learner centered teaching methods, presence of teaching and learning materials, nature of class size, nature of the topic, academic abilities of the students either a faster learner or slow learner, teacher workload, shortage of time and shortage of teacher in the schools (Komba\&Ndalichako 2014). Teachers who have negative perceptions towards learner centered teaching methods, the learning style is difficult to the students and hence students were less creative and critical thinkers in their activities thus, this method was not successful. No studies have established the effectiveness of learner centered methods in the teaching and learning process in public secondary schools in the Moshi District. Therefore, this study investigates the effectiveness of learner centered teaching methods in the teaching and learning process in public secondary schools Moshi District Council.

\section{Statement of the Problem}

The unwillingness of teachers to use learner centered teaching methods is a common problem in most public secondary schools (Keiler, 2018). The majority of teachers are reported not to use learner centered methods during teaching and learning thus resulting in the low academic achievement of students (Kanyonga, Mtana, and Wendt, 2019). Education stakeholders including heads of schools complain that teachers do not use learner centered methods during the teaching and learning process. This has been associated with many factors like shortage of teaching and learning materials as a result teachers fail to involve student's participation in the teaching and learning process. Student's active participation during the teaching and learning process might be influenced by the presence of teachers who are equipped with skills to use learner centered methods when teaching students.Many studies like those of Mombo, (2018), Daniel, (2018), Nara, (2017) researched the use of learner centered teaching methods in students' achievements. However, the studies have not touched on the application of learner-centered teaching methods to enhance the teaching and learning process in public secondary schools. Most teachers are not willing to use learner centered teaching methods thus results in students not mastering the subject concepts, this makes the researcher want to investigate the effectiveness of learner centered teaching methodsmost teachers are not willing to use them.

\section{Research Questions}

This study was guided by the following research question

1. To what extent do teachers apply learner-centered teachingmethodsduring the teaching and learning process in public secondary schools in the Moshi District Council?

\section{Significance of the Study}

The findings of this study provide awareness to the policymakers about the cause of teachers not use learner centered teachingmethods during the teaching and learning process. The findings of this study provide awareness to the public and education stakeholders on the importance of using learner centered teaching methods on enhancing teaching and learning process. The findings of the study provide knowledge to the teacher and other education stakeholders about the factors that facilitate the use of learner centered teaching methods. Furthermore, the study also provides awareness to the education stakeholders on how teachers and students perceive the implementation of learner centered methods during teaching and learning.

\section{Conceptual Framework}

The conceptual framework shows the relationship between independent variable which is learner centered teaching methods and the dependent variable which is the teaching and learning process.

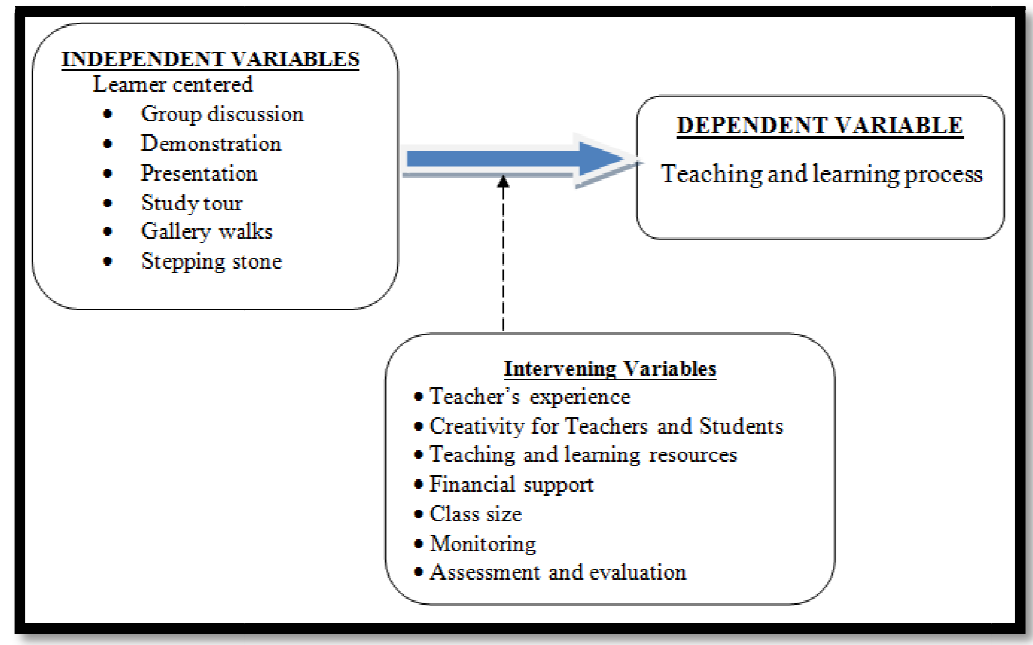

Figure 1: Conceptual Framework

Source: Researcher Design (2021) 
Figure 1 shows the relationship between independent variables and dependent variables. In the implementation of teaching and learning process group discussion improves students thinking, listening and speaking skills. It also promotes student's confidence level. It is an effective teaching method in problem solving, decision making and personality assessment. Group discussion skills may ensure the academic success and popularity of students. Teacher demonstrations are important because they provide students with experiences of real events, phenomena and processes, helping them learn. raise students' interest and motivation. enable you to focus students on a particular phenomenon or event.

Presentation skills help create innovative ideas when students come up with creative and interesting slides to illustrate their talk. Students are usually given 10 to 15 minutes to present a specific topic in the classroom. Thus, the more talks they give, the more they will learn. Educational field trips help teachers widen their horizons of knowledge and broadening the scope of their syllabus. Most educational trips pay much attention to outdoor activities with a wide range of aspects in life. It means the trips allow the teacher to connect the classroom with real-life and authentic experiences. This discussion technique allows students to be actively engaged as they walk throughout the classroom. They work together in small groups to share ideas and respond to meaningful questions, documents, images, problem-solving situations or texts.

The conceptual framework relates to social constructivism. Expert teachers use good constructivist theories in teaching and learning by following some of the guiding principles such as use coaching and scaffolding to build student understanding, encourage and support student initiative and autonomy, make openness and tolerance basic rules for classroom interaction, frame tasks using processes such as classifying, analyzing, predicting and creating, encourage student dialogue both with the teacher and with each other, use raw data and primary sources as well as manipulative, interactive, physical materials and create thinking and problem solving environment as well as organize instruction to facilitate knowledge construction. All these principles support the application of learner-centered teaching methods in the teaching and learning process.

\section{Review of Empirical Studies}

This section presents the related studies from different nations concerning the application of learner centred teaching methods on enhancing teaching and learning process.

\subsection{The Application of Learner-Centered Teaching Methods on Enhancing Teaching and Learning Process}

Nyimbili, Namuyamba and Chakanika (2018) conducted a study on the use of learner centered techniques in the teaching of English language in selected secondary schools of Lundazi District in Zambia. The study used a qualitative in which case study was used. The study targeted 50 students, 20 teachers and 10 academic teachers and 9 heads of schools that make a total of a population of 99 respondents. They used an interview guide and a document analysis guide. The findings revealed that teachers were not interested in teaching using learner centered techniques hence they used a limited number of learners centered activities. Despite this, students were interested in learning English using the learner centered activities.

The researcher did not establish how teachers were using those limited number of learners centered activities during teaching and learning process. The sample size of the study did not correspond with the design used in the study since the case study design allowa large number of respondents. The current study used mixed design which allows the researcher to employ a large number of respondents so that to collect a large number at one time. The study used an interview guide and document analysis guide which do not provide statistical data. The current study used a questionnaire and interview schedule to collect a large amount of data at one time.

Zabeli, Anderson \&Saqipi, (2018) conducted a study towards the development and implementation of learnercentered education in Kosovo. In this study, 36 practising teachers responded to a survey exploring how teachers understand and use contemporary and traditional teaching methodologies. Using a largely qualitative analytic framework, findings revealed that teachers currently appear to understand the philosophy of learner-centered teaching but also possessed a rather superficial view of how these teaching methods can be implemented in classroom settings. The researchers concluded that to broaden the use of these kinds of practices, deliberate emphasis needs to be placed on expanding teacher understanding from theory to practice. The findings of the study have shown the understanding of the teachers on the use of learner centered teaching methods while they did not establish how the teacher can use learner centered teaching methods during teaching and learning process. The sample size of the study was small compared with the design used, then it will be difficult to generalized the findings from the target population. The current study adopted a mixed design which allows the researcher to collect a large amount of data at one time. The study sampled 217 respondents to triangulate the information in different categories of respondents.

A qualitative study was done by Langu (2017) on the effectiveness of learner-centered teaching methods in teaching and learning Geography in Nkoaranga and Nasholi secondary schools Arumeru District. 30 students, 5 teachers and 2 heads of schools are the study target. The study used questionnaires during the data collection process. The finding show that learner centered teaching methods has been used often through teaching and learning process. Methods of group discussion as the provision of changes to ask questions or share views, group assignment and homework here used to help learners to understand the lesson thus contributing to the improvement in student's achievements. The study findings have explained only group discussion as one among learner centered teaching strategies while other teaching strategies like think presentation, role play and demonstration have been explained which are also used during the implementation of learner centered teaching methods. The study used only a questionnaire during the data collection process to all study respondents, this reflects inadequate reliable data collection since the researcher got the same data. 
This study used questionnaires and an interview guide to collect data that differ from the corresponding respondents to get qualitative and quantitative data.

Kamugisha (2019) did a study about the use of learner-centered teaching methods and materials in teaching and learning social science subjects in Tanzania Secondary Schools. A quasi-experimental design was employed. Then, quantitative teaching methods were employed under which experimental design was used. A questionnaire was used during data collection and analysis. The researcher sample 20 students, 4 teachers and 1 head of school. The study revealed that the material designed and the teaching methods used in the experimental school motivated the students in learning. The study indicates students of the experimental school showed considerable change in performance in the posttest compared to the students of the control school. The study did not explain the application of learner centred teaching methods on enhancing teaching and learning process. Similarly, the study used a quasi-experimental design that allow the researcher to collect only quantitative data. The current study used a convergent design which enable the researcher to collect both qualitative and quantitative data.

Buditama (2017) did a study on the student-centered learning teaching methods in teaching basic grammar. The method used in this research is quasi-experimental methods (quasi). The study used a mixed design with a mailed questionnaire for teachers and an interview guide for teacher educators and principals. Teachers, teacher educators and principals were surveyed randomly to participate in the study. The study involved 73 teachers 4 teacher educators and 4 principals. The study found that majority of the students were active and enthusiastic, but half of the students need more attention from the teacher in the learning process. Thus, the students found it difficult to answer and respond to the teacher's questions and explanations. They were also shy and not confident to present their writings in front of the class. The study findings are based only on English grammar subjects in investigating the use of learner centered teaching methods in which it can be difficult for students to participate due to foreign languages. The sample size for the teacher educators and the principals was a little bit small to make the findings of the study to be generalized to the target population. This reflects inadequate empirical knowledge in parental relations that needs to be established.

\section{Methodology}

In this study, the researcher adopted a mixed methods approach under which a convergent design was used. A convergent parallel design involves a simultaneous collection of both quantitative and qualitative data to gain a deeper understanding of the research problem. The advantage of this design is that it combines the virtues of both qualitative and quantitative data whereby quantitative data allows making generalizations and qualitative data provides information about the context (Creswell, 2012).The target population of this study was 59 academic teachers, 473 Teachers, 1589 form four students and 59 Heads of schools in the Moshi District council (Moshi District Education Office, 2021). However, the study sampled 8 heads of schools, 8 academic teachers, 48 teachers and 160 form four students from 8 secondary schools and 1 District education officer, making a total number of 217 respondents.

Information for this study was collected using questionnaires for students and teachers while an interview guide was used for academic teacher, heads of schools and District education officer. Observation guide was used to collect data that was direct observable to the field. The three (3) data collection instruments were used in this study to ensure triangulation of the various responses. The researcher edited, coded, and organized quantitative data in a way that made interpretations possible before concluding. For quantitative data, the researcher used both descriptive and inferential statistics to organize the collected data. Descriptive analysis was involved in organizing data in terms of frequency, percentages and means where computer software that is statistical package for social science (SPSS) version 22 was used. Inferential analysis was involved in the use of statistical techniques to test the study hypotheses whereby an independent sample t-test was used at a 95\% confidence level. Tables cross tabulation was used to present the quantitative data.

\section{Findings and Discussion}

The research questions intended to determine the application of learner-centered teaching methods on enhancing teaching and learning process and the factors influencing the use of learner centred teaching methodson enhancing teaching and learning processin public secondary schools in Moshi District Council.

\section{Application of Learner Centered Teaching Methods on Enhancing Teaching and Learning Process}

This section of the first research question research aimed at finding out the application of learner centered methods on enhancing the teaching and learning process. Information to address this question was acquired from students, teachers, academic teachers and heads of schools. Table 1 presents responses from students on the application of learner centered teaching methods on enhancing teaching and learning process. 


\begin{tabular}{|c|c|c|c|c|c|c|c|c|c|c|c|}
\hline \multirow{2}{*}{$\begin{array}{l}\text { Application of Learner Centred } \\
\text { Teaching Methods }\end{array}$} & \multicolumn{2}{|c|}{ SD } & \multicolumn{2}{|c|}{ D } & \multicolumn{2}{|c|}{$\mathbf{U}$} & \multicolumn{2}{|c|}{ A } & \multicolumn{2}{|c|}{ SA } & \multirow[b]{2}{*}{ Mean } \\
\hline & f & $\%$ & f & $\%$ & f & $\%$ & f & $\%$ & f & $\%$ & \\
\hline $\begin{array}{c}\text { My teachers use presentation } \\
\text { during teaching and learning } \\
\text { process }\end{array}$ & 16 & 10.0 & 14 & 8.8 & 20 & 12.5 & 36 & 22.5 & 74 & 46.3 & 3.72 \\
\hline $\begin{array}{l}\text { My teachers encourage us to } \\
\text { discuss in small groups at the mid } \\
\text { of the lesson }\end{array}$ & 14 & 8.8 & 28 & 17.5 & 8 & 5.0 & 70 & 43.8 & 40 & 25.0 & 3.59 \\
\hline $\begin{array}{l}\text { My teacher use dramatization to } \\
\text { teach a complex topic }\end{array}$ & 60 & 37.5 & 46 & 28.7 & 26 & 16.3 & 18 & 11.3 & 10 & 6.3 & 3.03 \\
\hline $\begin{array}{l}\text { My teachers use questions and } \\
\text { answers at the beginning of the } \\
\text { lesson to measure if we are } \\
\text { remembering the last subject } \\
\text { concepts }\end{array}$ & 16 & 10.0 & 29 & 18.1 & 1 & 0.6 & 33 & 20.6 & 81 & 50.6 & 3.84 \\
\hline $\begin{array}{l}\text { My teachers encourage us to work } \\
\text { in pair during our private studies }\end{array}$ & 20 & 12.5 & 7 & 4.4 & 11 & 6.9 & 60 & 37.5 & 62 & 38.8 & 3.86 \\
\hline $\begin{array}{l}\text { My teachers use debate to make } \\
\text { us compete with different classes }\end{array}$ & 0 & 0.0 & 0 & 0.0 & 0 & 0.0 & 47 & 29.4 & 113 & 70.6 & 3.65 \\
\hline $\begin{array}{c}\text { My teachers allow us to make } \\
\text { discussion when doing class } \\
\text { assignment }\end{array}$ & 8 & 5.0 & 19 & 11.9 & 5 & 3.1 & 78 & 48.8 & 50 & 31.3 & 3.89 \\
\hline $\begin{array}{l}\text { My teachers use team teaching } \\
\text { methods when teaching difficult } \\
\text { subject concepts }\end{array}$ & 0 & 0.0 & 0 & 0.0 & 95 & 59.4 & 38 & 23.8 & 27 & 16.9 & 3.46 \\
\hline $\begin{array}{l}\text { My teachers use role play to } \\
\text { influence explicitly skills } \\
\text { instruction }\end{array}$ & 4 & 2.5 & 0 & 0.0 & 88 & 55.0 & 56 & 35.0 & 12 & 7.5 & 4.04 \\
\hline $\begin{array}{c}\text { My teachers used project to make } \\
\text { us investigate of the different } \\
\text { problems concerning education } \\
\text { issues }\end{array}$ & 71 & 44.4 & 36 & 22.5 & 1 & 0.6 & 22 & 13.8 & 30 & 18.8 & 4.52 \\
\hline Total Mean Score & & & & & & & & & & & 3.37 \\
\hline
\end{tabular}

Table 1: Application of Learner Centered Teaching Methodson Enhancing Teaching and Learning Process(N=160) Source: Field Data, (2021): M=Mean Score

Key: $S A=$ Strongly Agree, $A=$ Agree, $U=$ Undecided, $D=$ Disagree, $S D=$ Strongly Disagree

The responses from the students in Table 1 shows that teachers applied learner centred teaching methods when teaching students $(M=3.37)$. This means that students have participated in the teaching methods used by the teacher when teaching students. Results from Table 1 show that (68.8\%) of students agreed to the statement that teachers use presentation during teaching and learning process while(18.8\%) of students disagreed to the statement and (12.5\%) of students are undecided to the statement, (68.8\%) of students agreed to the statement that teachers encourage students to discuss in small groups at the mid of the lesson while (26.3\%) of students disagreed to the statement and(5.0\%) of students are undecided to the statement, (71.2\%) of students agreed to the statement that teachers use questions and answers at the beginning of the lesson to measure if we are remembering the last subject concepts while (28.1\%) of students disagreed to the statement and $(0.6 \%)$ of student is undecided, $(80.1 \%)$ of students agreed to the statement that teachers allow students to make discussion when doing class assignment while (16.9\%) of students disagreed to the statement and (3.1\%) of students are undecided to the statement, $(66.9 \%)$ of students disagreed to the statement that teachers used project to make us investigate of the different problems concerning education issues, (90.0\%) of students disagreed to the statement that teachers use role play to influence explicitly skills instruction.

The findings implied that learner centred methods were applied at public secondary schools where teachingmethods that make students fully participate during teaching and learning are very few. The findings revealed that presentation, questions and answers and discussions were indicated by the students to be highly used during the teaching and learning process. Iddy\&Chiwanga, (2017) argued that Teachers in public secondary schools largely used teacher centered teaching methods as they encountered transitional challenges such as insufficient instructional materials, overcrowded classes, and poor proficiency of the English language which seemed to prevent them from effectively applying the LCA. This means that most students in public secondary schools do not actively participate during the teaching and learning process as a result majority of students do not understanding well the content that has been taught which lately will damage their achievements. During the interview with the heads of schools about the application of learner centered teaching methods during the teaching and learning process in improving students' achievements. The majority of the heads of schools agreed that teachers are applied learner centered teaching methods in their schools. One of the heads of schools said;

When I monitored school activities especially in the class during class sessions, I saw teachers asking students questions, conducting group discussions and other teachers for example those who teaching Kiswahili and English 
language they use dramatization and role-plays. So, in our school teachers use learner centered teaching methods during teaching students and improving students' achievements. (24th May 2021).

Another head of school said;

In our school, teachers applied learner centred teaching methods during teaching and learning process. I saw teachers used to debate, group discussion, presentations, and questions and answers to encourage student's participation in the class session. (28 $8^{\text {th }}$ May 2021).

The findings from the heads of schools imply that learner centred teaching methods reapplied during teaching and learning process in their schools. However, some of the heads of schools are very busy with their leadership daily responsibilities but they find time to monitor and inspect teacher's lesson plans to identify if teachers are teaching their students well. Heads of schools showing the importance of using learner centered teaching methods by effectively employing its strategies in teaching process as it results in learners being active in learning and generating interactions with materials, interaction with themselves and with teachers as well as to improve students' achievements.

In learner centred teaching methods, students should be provided with various ways and forms of accessing learning materials because students have different learning abilities. Certain ways of teaching are only suitable for certain learning materials, while there are many materials to be taught to students. If students are only provided one way of teaching methods, it tends to be boring and students lack interest in participating actively. Therefore, teachers must use several learner centred teaching strategies to encourage students to actively participate during teaching and learning process. To triangulate the information researcher was asked the same question to the teachers to investigate how the teachers apply learner centred teaching methods. Table 2 presents teachers' responses on the application of learner centred teaching methodson enhancing teaching and learning process.

\begin{tabular}{|c|c|c|c|c|c|c|c|c|c|c|c|}
\hline \multirow[t]{2}{*}{ Statement } & \multicolumn{2}{|c|}{ SD } & \multicolumn{2}{|c|}{ D } & \multicolumn{2}{|c|}{$\mathbf{U}$} & \multicolumn{2}{|c|}{ A } & \multicolumn{2}{|c|}{ SA } & \multirow[b]{2}{*}{ Mean } \\
\hline & f & $\%$ & f & $\%$ & f & $\%$ & f & $\%$ & f & $\%$ & \\
\hline $\begin{array}{l}\text { I use learner centred teaching } \\
\text { methods when there is high } \\
\text { number of students in the class }\end{array}$ & 26 & 54.2 & 10 & 20.8 & 2 & 4.2 & 6 & 12.5 & 4 & 8.3 & 4.71 \\
\hline $\begin{array}{c}\text { I use learner centred teaching } \\
\text { methods to teach students on how } \\
\text { to think, solve problems and } \\
\text { evaluate evidence }\end{array}$ & 0 & 0.0 & 0 & 0.0 & 0 & 0.0 & 28 & 58.3 & 20 & 41.7 & 4.42 \\
\hline $\begin{array}{l}\text { I use learner centred teaching } \\
\text { methods to teach students } \\
\text { learning skills that are essential to } \\
\text { mastering materials }\end{array}$ & 0 & 0.0 & 0 & 0.0 & 0 & 0.0 & 13 & 27.1 & 35 & 72.9 & 4.73 \\
\hline $\begin{array}{c}\text { I use learner centred teaching } \\
\text { methods to make students reflect } \\
\text { on the content taught }\end{array}$ & 0 & 0.0 & 2 & 4.2 & 0 & 0.0 & 15 & 31.3 & 31 & 64.6 & 4.56 \\
\hline $\begin{array}{l}\text { I use learner centred teaching } \\
\text { methods encourage students to } \\
\text { work in pair, groups or } \\
\text { presentation }\end{array}$ & 0 & 0.0 & 0 & 0.0 & 2 & 4.2 & 18 & 37.5 & 28 & 58.3 & 4.54 \\
\hline $\begin{array}{l}\text { I use learner centred teaching } \\
\text { methods to motivate students by } \\
\text { giving them some control over } \\
\text { learning process }\end{array}$ & 0 & 0.0 & 0 & 0.0 & 3 & 6.3 & 9 & 18.8 & 36 & 75.0 & 4.69 \\
\hline $\begin{array}{l}\text { I use learner centred teaching } \\
\text { methods to encourage student's } \\
\text { collaboration between students } \\
\text { themselves }\end{array}$ & 0 & 0.0 & 0 & 0.0 & 0 & 0.0 & 7 & 14.6 & 41 & 85.4 & 4.85 \\
\hline $\begin{array}{l}\text { I use learner centred teaching } \\
\text { methods depending on the nature } \\
\text { of the subject }\end{array}$ & 0 & 0.0 & 0 & 0.0 & 2 & 4.2 & 15 & 31.3 & 31 & 64.6 & 4.60 \\
\hline $\begin{array}{c}\text { I used learner centred teaching } \\
\text { methods to influence explicitly } \\
\text { skills instruction }\end{array}$ & 0 & 0.0 & 2 & 4.2 & 0 & 0.0 & 22 & 45.8 & 24 & 50.0 & 4.42 \\
\hline $\begin{array}{c}\text { I use learner centred teaching } \\
\text { methods to pave the road to } \\
\text { learner success }\end{array}$ & 0 & 0.0 & 0 & 0.0 & 0 & 0.0 & 10 & 20.8 & 38 & 79.2 & 4.79 \\
\hline Total mean score & & & & & & & & & & & 4.63 \\
\hline
\end{tabular}

Table 2: Application of Learner Centered Teaching Methodson Enhancing Teaching and Learning Process (N=48) Source: Field Data, (2021)

Key: $S A=$ Strongly Agree, $A=$ Agree, $U=$ No Opinion, $D=$ Disagree, $S D=$ Strongly Disagree

The findings from Table 2 show that teachers agreed to use learner centred methods when teaching students $(\mathrm{M}=4.63)$. The findings from Table 2 indicated that all of the teachers agreed that they use learner centred teaching 
methods to teach students how to think, solve problems and evaluate evidence, all teachers agreed that they use learner centred teaching methods to teach students learning skills that are essential to mastering materials, all of the teachers agreed that they use learner centred teaching methods to encourage student's collaboration between students themselves, all of teachers agreed that they used learner centred teaching methods to influence explicitly skills instruction, all of teachers agreed that they use learner centred teaching methods to pave the road to learner success, $(75.0 \%)$ of teachers disagreed to the statement that teachers use learner centred teaching methods when there is high number of students in the class while $(2.8 \%)$ of teachers agreed to the statement and $(4.2 \%)$ of teachers are undecided to the statement. The findings imply that teachers in public secondary schools are using learner centred teaching methods during teaching and learning process. The use of learner-centered teaching methods provides opportunities for the learners to construct their knowledge and use it in the society outside the school contexts.

Learner cantered methods is an approach in which students have control over the learning process. With the learner cantered teaching methods, teachers function as facilitators of learning rather than lecturers. In this way, teachers do less telling; students do more discovering. The roles of the teacher in the learner-cantered approach are to design the course such that it creates a climate for an optimal learning; model the appropriate expected behaviour for the students; encourage students to learn from and with each other; and provide more feedback throughout the process (Mombo, 2018). Learner cantered teaching methods forces students to play an active role in their education, as opposed to the more passive role traditionally used.

Teachers have to use learner centred teaching methods that help every student to understand the subject being taught as a result to improve students' achievements. When teachers utilize multiple teaching techniques appropriate for student learning goals such as small group discussion, answered question, and review content. Certain teaching methods are only suitable for students who have a particular learning style. If teachers use only one methods, it is certain that students who have a particular learning style will become bored and cannot achieve the expected learning objectives (KItta \& Tilya, 2018). Various teaching techniques are expected to be implemented in learner-cantered teaching methods to accommodate various learners' characteristics and needs including their learning style. Besides, the use of a variety of teaching techniques following the learning materials will make students have a deeper understanding of the material.

During observation done by the researcher at every public secondary school, a researcher observed that teachers indicate the use of various learner centred teaching methods in their lesson plans. Most teachers indicate the use of more than two teaching techniques that imply the participation of students during teaching and learning process. Most of teaching techniques used indicated by the teachers are debate, presentations, role play, case study, question and answers, group discussion and think pair share. However, at the class during the class sessions majority of teachers were observed to use only one teaching technique and others are not using any teaching techniques that they have been indicated in their lesson plan. This means that the majority of teachers use learner centred teaching methods at a minimum rate since most of them do not follow what they have been written in their lesson plans. Learner centred teaching and learning are accompanied by learning methods such as brainstorming, role play, demonstration, presentation and gallery walk. During the interview with the DEO about the application of learner centred teaching methods in public secondary schools in the District, the DEO indicated that learner centred teaching methods is used by all teachers to all secondary schools in the district. DEO said that;

I always advise teachers and their heads of school to use learner centered teaching methods because the new paradigm shift of our curriculum to the competence-based curriculum of 2005-2007 directs us to use it...Due to different limitations, group discussion, debate and demonstration are mostly used by majority of teachers during teaching students because they are easy to apply within the shortage of learning and teaching materials. $\left(25^{\text {th }}\right.$ May 2021).

The findings from DEO imply that teachers apply learner centered teaching methods despite a shortage of teaching and learning resources. The findings indicated that teachers were aware of and prepare lesson plans related learner centered teaching methods even if there were a shortage of funds for resources and facilities especially in the rural schools to implement them appropriately. Also, DEO emphasized the use of available materials and facilities to improvise and produce different models and teaching aids and to use talented learners as a resource.

This study found that learner centred teaching methods were applied at a moderate rate in most public secondary schools in the Moshi district. The study was found that majority of teachers are indicated more than two learning strategies that are used in learner centred teaching methods but they use only one and other teachers they didn't use at all. The study also found that the District Education Officer emphasises the use of learner centred teaching methods since it's the new paradigm shift to competence-based-curriculum then teachers must use learner centred teaching methods during teaching and learning process. The findings show that the effective implementation of learner-centered teaching methods in secondary schools needs the availability of teaching and learning materials like enough books, teaching models and aids, laboratory facilities like chemicals and apparatus.

Based on the findings the study concluded that teachers have to use presentations during teaching and learning process. Use of presentation by teachers during teaching and learning process improve student's ability to cooperate with other students during learning. Teachers have to use presentations, questions and answers and discussions to make lessons interestingfor the students. Teachers must use several learner centred teaching strategies to encourage students to actively participate during the teaching and learning process. The roles of the teacher in the learner-cantered approach are to design the course such that it creates a climate for optimal learning; model the appropriate expected behaviour for the students; encourage students to learn from and with each other, and provide more feedback throughout the process 


\section{Conclusion}

Based on the findings, it was concludedteachers applied learner centred teaching methods to encourage students to be actively participated during the teaching and learning process. Teachers used presentation, question and answers and discussion to make the lesson interesting to the students. The roles of the teacher in the learner-cantered teaching methods are to design the course such that it creates a climate for optimal learning; model the appropriate expected behaviour for the students; encourage students to learn from and with each other; and provide more feedback throughout the process

\section{Recommendation}

The study recommended that the government through the Ministry of Education Science and Technology (MOEST) should allocate enough funds to secondary schools for buying teaching and learning material that supported the application of learner centred teaching methods. The government also should provide a training course for in-service teachers about learner centered teaching methods. Heads of schools should provide proper supervision of teaching and learning process by ensuring that learner centered teaching methods was applied during teaching and learning process. Students should cooperate with their teachers at class session.

\section{References}

i. Beinomugisha, P. Jagero, N. and Rwashema. E. (2012). The Perceptions of Postgraduate Students towards the Teaching Strategies Employed by CENTED Lecturers in IIUM; International Journal of Academic Research in Progressive Education and Development January 2012, Vol.1, No. 1 ISSN: 2226-6348.

ii. Buditama, M. (2017). Student-centered learning teaching methods in teaching basic grammar. Journal on English as a Foreign Language, 7(2), 209. https://doi.org/10.23971/jefl.v7i2.534

iii. Daniel, W. (2018). Youth Participatory Action Research as Culturally Sustaining Pedagogy. Theory Into Practice, 57(2), 127-136. https://doi.org/10.1080/00405841.2018.1433939

iv. Iddy, S., \&Chiwanga, F. E. (2017). Is the learner-centred approach indeed adopted in the teaching-learning of French in O-level state secondary schools in Dar es Salaam, Tanzania? Education Research Journal, 7(6), 11.

v. Kamugisha, D. N. A. (2019). The Use of Learner-Centered Teaching methods and Materials in Teaching and Learning Social Science Subjects in Tanzania Secondary Schools. International Journal of Research and Innovation in Social Science (IJRISS), 3(8), 10.

vi. Kanyonga, L., Mtana, N., \& Wendt, H. (2019). Implementation of competence-based curriculum in technical colleges: The case of Arusha City, Tanzania. International Journal of Vocational and Technical Education, 11, 120. https://doi.org/10.5897/IJVTE2018.0262

vii. Keiler, L. S. (2018). Teachers' roles and identities in student-centered classrooms. International Journal of STEM Education, 5(1), 34. https://doi.org/10.1186/s40594-018-0131-6

viii. Kitta, S., \&Tilya, F. (2018). Assessment Status of Learner Centred Learning in Tanzania in the Context of the Competence Based Curriculum. IIUM Journal of Educational Studies, 1(1), 14.

ix. Komba, S. C., \&Mwandaji, M. (2015). Reflections on the Implementation of Competence Based Curriculum in Tanzanian Secondary Schools. Journal of Education and Learning, 4(2), p73. https://doi.org/10.5539/jel.v4n2p73

x. Mombo, E. N. (2018). Assessment of the Implementation of Learner-Centered Teaching Approaches in Secondary Schools in Tanzania: A Case of Bahi District [Dissertation]. The University of Dodoma.

xi. Nara, A. T. (2017). Assessing the Impact of Competence-Based Curriculum on Students "Learning Habits in Tanzania: Dar es Salaam: University of Dar es Salaam.

xii. Nyimbili, F., Namuyamba, M., \&Chakanika, W. (2018). The Use of Learner Centered Techniques in the Teaching of English Language in Selected Secondary Schools of Lundazi District. International Journal of Humanities, Social Sciences and Education, 5(3), 7. https://doi.org/10.20431/2349-0381.0503015

xiii. Simasiku, L. (2011). The pupil's and Teacher's Perceptions of Learner centred Methods in the Teaching and Learning of History. (Unpublished Masters Dissertation, UNZA).

xiv. Tilya, F. and Mafumiko, F. (2010). The Compatibility between Teaching Methods and Competence-based Curriculum in Tanzania. Papers in Education and Development, 29, 37-56.

xv. URT, (2010). Education Sector Development Programme: Secondary Education Development Programme Phase Two (2010/11-2014/15. Dar es Salaam: MoEVT.

xvi. Weimer, M. (2013). Learner-centered teaching: Five key changes to practice. San Franscisco, CA: Jossey Bass.

xvii. Zabeli, N., Anderson, J. A., \&Saqipi, B. (2018). Towards Development and Implementation of Learner-Centred Education in Kosovo. Journal of Social Studies Education Research, 9(4), 49-64. 